
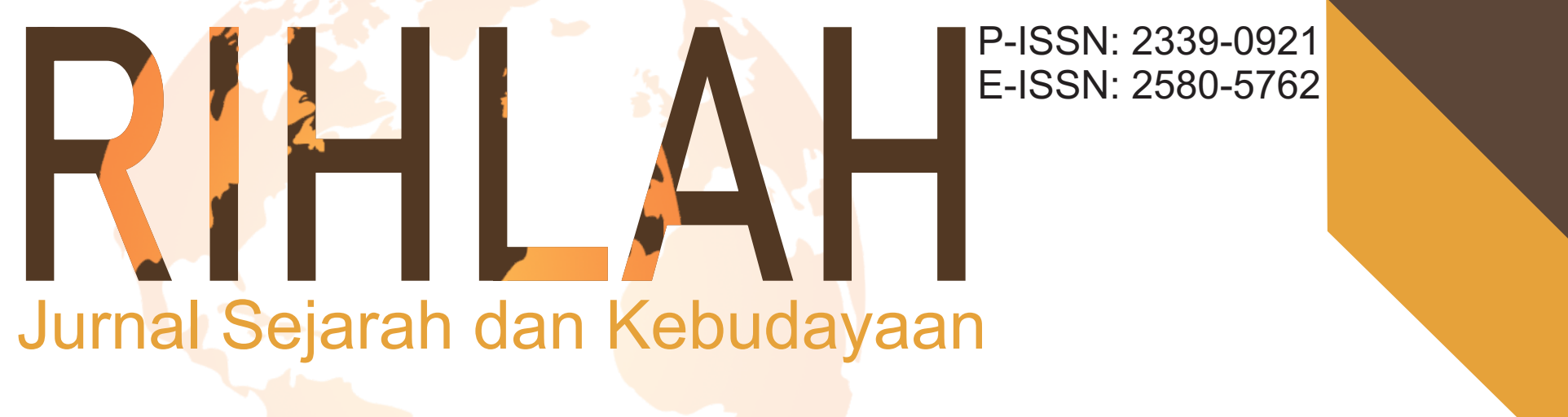

Article

Kebangkitan Kesultanan Ternate pada Era Reformasi 1998-2002 Rustam Hasyim, Oktosiyanti MT Abdullah, Siti Rahia H. Umar

Kondisi Politik Persia pada Era Dinasti Qajar 1796-1834 M Arafah Paramasto

Sultan Abdul Qahir dalam Pengembangan Islam di Bima Rahmat, Nurwahidah

Eksistensi Maccera Manurung dalam Perspektif Nilai Islam Sitti Fatimah Dwi Putri Islam dalam Tradisi Pernikahan Nuraeni

The Developments and Problems of Muslims in Australia Syamzan Syukur, Syamhi Muawwan, Syarifah Fauziah

Book Review

Historiografi Korupsi di Indonesia: Resensi Buku Korupsi dalam Miftakhuddin

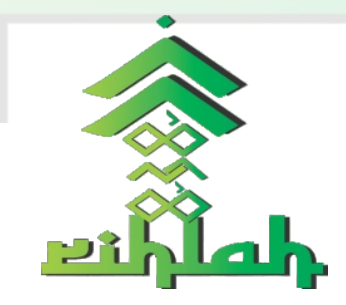




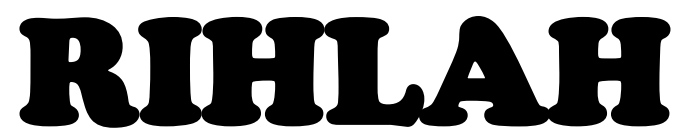

Jurnal Sejarah dan Kebudayaan

\begin{tabular}{|c|c|}
\hline Editor in Chief & Dr. Rahmat, M.Pd. \\
\hline Managing Editor & Mastanning, S.Hum, M.Hum. \\
\hline Editorial Board & $\begin{array}{l}\text { Nur Ahsan Syukur, S.Ag, M.Si. } \\
\text { Muh. Iqbal S.Hum, M.Hum. } \\
\text { Chaerul Munzir, S.Hum, M.Hum. } \\
\text { Lydia Megawati, S.Hum, M.Hum. } \\
\text { Muhammad Husni, S.Hum, M.Hum. } \\
\text { Zaenal Abidin, S.S., M.H.I. } \\
\text { Chusnul Chatimah Asmad, S.IP, M.M. } \\
\text { Muhammad Arif, S.Hum, M.Hum. }\end{array}$ \\
\hline Desain Grafis & Nur Arifin, S.IP. \\
\hline Secretariat & Safaruddin, S.Hum. \\
\hline Reviewers & $\begin{array}{l}\text { Prof. Dr. H. Abd. Rahim Yunus, M.A. } \\
\text { Prof. Dr. H. Ahmad M. Sewang, M.Ag. } \\
\text { Dr. Hj Syamzan Syukur, M.Ag. } \\
\text { Dr. Nasruddin Ibrahim. } \\
\text { Dr. Abd. Rahman Hamid. } \\
\text { St. Junaeda, M.Hum. } \\
\text { Dr. Syamhari, M.Pd. } \\
\text { Dr. A. Sukri Samsuri, M.Pd. }\end{array}$ \\
\hline
\end{tabular}

Alamat Redaksi dan Tata Usaha : Jurusan Sejarah dan Kebudayaan Islam Fakultas Adab dan Humaniora UIN Alauddin Makassar, Jln. Sultan Alauddin No. 36 Samata Gowa Tlp. 0411-841879 Fax. 0411-822140 (Kampus II) E.Mail. rihlah@uin-alauddin.ac.id

Jurnal Rihlah terbit dua kali dalam setahun, bulan Juni dan bulan Desember berisi kajian tentang Sejarah dan Kebudayaan, baik dari hasil penelitian maupun tulisan ilmiah lainnya.

Penyunting menerima tulisan yang belum pernah diterbitkan oleh media cetak lain. Naskah diketik spasi $1 \mathrm{~cm}$ pada kertas berukuran A4 dengan tulisan berkisar 12-23 halaman. Naskah yang masuk dievaluasi oleh Dewan Penyunting. Penyunting dapat melakukan perubahan pada tulisan yang dimuat untuk keseraganan format, tanpa mengubah maksud dan konten tulisan. 


\section{Daftar Isi}

Rustam, Oktosiyanti, Rahia

69-103

Kebangkitan Kesultanan Ternate pada Era Reformasi 1998-2002

Arafah Pramsto

104-125

Kondisi Politik Persia pada Era Dinasti Qajar 1796-1834

Rahmat, Nurwahidah

126-136

Sultan Abdul Qahir dalam Pengembangan Islam di Indonesia

Sitti Fatimah Dwi Putri

$.137-148$

Eksistensi Maccera Manurung dalam Perspektif Nili Islam

Nuraeni

$.149-158$

Islam dalam Tradisi Pernikahan

Syamzan, Syamhi, Syarifah 159-167

The Developments and Problems of Muslims in Australia

Miftakhuddin 168-172

Historiografi Korupsi di Indonesia: Resensi Buku dalam Silang

Sejarah Indonesia 


\title{
SULTAN ABDUL QAHIR DALAM PENGEMBANGAN ISLAM DI BIMA
}

\author{
Rahmat dan Nurwahidah \\ Universitas Islam Negeri Alauddin Makassar \\ Rahmat.ski04@uin-alauddin.ac.id \\ wahidahnurwahidah059@gmail.com
}

\section{Abstract}

Regarding Sultan Abdul Qahir is very interesting because since he was appointed by the king of Gowa and embraced Islam became the beginning of the development of Islam in Bima. Education as the main channel of Islamization is carried out in households raised by parents and ulemas, religious teachers such as the art of reading barzanji which is still valid in the villages. Carving, seen in the pulpit of the mosque, heirloom keris carved in such a way that it looks very beautiful grooves. Hadra, which is a kind of Islamic art in the form of dhikr in Arabic while shaking the body according to the tambourine rhythm which is done by sitting also standing. The second channel is a fairly successful propaganda method carried out by preachers is by approaching the community such as, adjusting to the situation and conditions of the people who hold fast to the old beliefs of Animism and Dynamism. The method of preaching like the one above is to look at the situation and condition of the community indeed has been exemplified by the Prophet Muhammad.

Keywoard: Abdul Qadir, Development, Education, Da'wah and Islam.

\section{Abstrak}

Mengenai Sultan Abdul Qahir sangat menarik karena sejak Ia dilantik oleh raja Gowa dan memeluk Islam menjadi awal perkembangan Islam di Bima. Pendidikan sebagai saluran utama islamisasi dilakukan dalam rumah tangga yang diasuh oleh orang tua dan para ulama. Pelajaran untuk didikan anak dilingkungan kesultanan Bima waktu itu selain belajar agama Islam (rukun, iman, rukun Islam, thaharah, adab), juga untuk meyiapkan putraputrinya secara khsusus untuk tujuan-tujuan dan tanggung jawab yang dihadapinya dalam kehidupan mendatang. Kegiatan pendidikan Islam di istana sebagaimana yang diuraikan di atas membawa pengaruh yang luas dikalangan masyrakat, yang berdatangan untuk belajar agama Islam dan berguru kepada mubalig/guru di istana untuk beberapa lama. Saluran kedua dengan cara pendekatan kepada masyarakat seperti, penyesuaian diri dengan situasi dan kondisi masyarakat yang berpegang teguh pada kepercayaan lama Animisme dan Dinamisme. Metode dakwah yang seperti 
tersebut diatas adalah dengan melihat situasi dan kondisi masyarakat memang sudah dicontohkan oleh Nabi Muhammad saw.

Kata Kunci: Abdul Qadir, Pengebangan, Pendidikan, Dakwah dan Islam

\section{Pendahuluan}

Sultan Abdul Qahir (La kai rumata bata wadu) adalah Sultan Bima yang pertama dalam sejarah kesultanan Bima. Beliau diangkat menjadi raja pada tahun 1030 H (1620 M) oleh raja Gowa sejak itulah Bima menjadi kerajaan Islam. ${ }^{1}$

Sejak Rumata ma bata wadu di lantik menjadi raja Islam yang pertama (1050 H) dengan gelar Sultan Abdul Qahir, agama Islam merupakan panutan seluruh masyarakat Bima, hanya sebagian kecil saja yang enggan menerima dan memeluk agama Islam. Mereka ingin menghindar dan mengundurkan diri ke daerah pegunungan yang sekarang di kalangan masyarakat Bima dikenal dengan sebutan "dou Donggo" (bahasa Bima), dou artinya orang, Donggo nama gunung jadi dou Donggo artinya orang gunung, dalam kutipan buku sejarah Bima yang disebutkan”

Demikianlah hanya masyarakat Bima pada masa itu mereka seluruhnya memeluk agama Islam, kecuali sebagian kecil yang menolak dan terdesak menghindarkan diri di pegunungan. Mereka dikenal dengan dou Donggo (orang Donggo) $^{2} \mathrm{Hal}$ yang sama disebutkan juga oleh Andan Taruna dalam Majalah Harmonis, 121 tahun VII Desember tahun 1996. "Bahwa seluruh rakyat Bima memeluk Islam, mereka yang tidak memeluk Islam menghindar kepegunungan. Mereka terdiri dari golongan penduduk yang sekarang di sebut orang Donggo". ${ }^{3}$

Dari keterangan di atas dapat disimpulkan bahwa sejak awal pemerintahan kesultanan Bima hampir seluruh rakyat Bima memeluk agama Islam. Sebagai bukti sampai sekarang ternyata penduduk Bima mayoritas beragama Islam. Penduduk yang non muslim tidak sampai $0,5 \%$ seperti Cina, pejabat, ABRI dan sipil yang kebetulan bertugas di Bima. Kalau masyarakat asli Bima yang memeluk agama bukan Islam ialah orang Donggo yang memang sejak berdirinya kesultanan Bima tidak menerima Islam. Tetapi berkat usaha Sultan Bima yang memerintah terutama Sultan Muhammad Salahuddin, masyarakat Donggo mendapat perhatian khusus yakni dengan mengirim beberapa orang mubaliq dan tenaga da'i di antara mereka yang dikirim dan pernah ditetapkan oleh Sultan Muhammad Salahuddin ialah H. Abdur Rahman Bandung lulusan Darul Ulum Mekkah dan terakhir ialah H. M. Kasim Lebbe Mbala/petugas khusus dari yayasan Islam Kabupaten Bima. Hasil dari usaha mereka dapat mempengaruhi dan menarik masyarakat Donggo menjadi penganut agama yang taat. Dan penduduk sedikit saja yang masih menganut agama

${ }^{1}$ Hj. Sitti Mariam R. Salahuddin ddk, Aksara Bima: Peradaban Lokal yang Sempat Hilang (Mataram : Alam Tara Institute, bekerjasama dengan : sampa raja kota bima, 2003),h. 19

${ }^{2}$ Ahmad Amin, Ringkasan Sejarah Bima., Bima: Kantor Kebudayaan Kabupaten Bima, 1971 hal. 50 .

${ }^{3}$ Andanang Taruna, "Sultan Abd. Hair" Majalah Harmoni, No. 121, Th. Ke VII, 1 Desember 1996. 
Islam. Jadi penduduk masyarakat Bima sejak zaman Sultan Abdul Qahir 1630 M. Sultan Bima yang pertama sampai pada zaman Sultan yang terakhir Muhammad Salahuddin, sampai sekarang agama Islam tetap menjadi panutan mayoritas penduduk Bima. Mereka memeluknya secara turun temurun, sekalipun pihak Kristen tetap melancarkan kristenisasi di seluruh penjuru Indonesia, termaksud juga daerah Bima belum berhasil dan tidak akan berhasil, karena masyarakat asli Bima sangat fanatik dengan agamanya (Islam), sementara agama kristen hanyalah bagi penduduk pendatang.

Mengenai Sultan Abdul Qahir sangat menarik karena sejak ia dilantik oleh raja Gowa dan memeluk Islam menjadi awal perkembangan Islam di Bima. Hal ini membantu peneliti untuk mendalami lebih dalam tentang Sultan Abdul Qahir dan peranannya dalam perkembangan Islam di Bima. Bidang pendidikan dan dakwah adalah saluran yang sangat mempengaruhi perkembangan Islam di Bima, karena menyesuaikan konsep keadaan dan ruang ligkup sangat strategis menyalurkan.

\section{Bidang Pendidikan}

Bidang pendidikan Merupakan saluran islamisasi yang tercatat dalam sejarah yang tidak kalah penting dari bidang lainnya. Pendidikan sebagai saluran islamisasi ini berlangsung dalam rumah tangga yang diasuh oleh orang tua dan para ulama, kiyai guru agama. Dalam lingkungan rumah tangga para orang tua mengajarkan agama kepada putra-putrinya dengan cerita berita dan dongeng yang pada umumnya bertemakan akhlak dan tata kesopanan. Adapun rumah tangga para raja dan kaum bangsawan pada umumnya mereka mendatangi ulama-ulama yang khusus mendidik dan mengajar mereka. Pondok pesantren merupakan tempat belajar yang mendidik putra dan putri diluar lingkungan rumah tangga, putra-putri mendatangi pondok pesantren untuk belajar agama kemudian kembali ke kampung untuk menyiarkan didaerah lain.

Kegiatan atau aktivis pendidikan diarahkan dalam bentuk dakwah dan ajakan masuk Islam, hal ini di lakukan oleh para mubalig/utusan dari raja Gowa dalam rangka pengislaman keluarga kerajaan. Adaya aktivis pendidikan ini diketahui setelah Abdul Qahir menjadi Sultan Bima yang pertama, beliau didampingi oleh kedua gurunya Datuk ri Bandang dan Datuk ri Tiro yang sekaligus merangkai sebagai penasehat. Sebelum gurunya meninggalkan Kesultanan sempat diadakan perjanjian dan sumpah setia antara sultan dengan mereka. Bunyi lengkap dari sumpah tersebut sebagai berikut:

Hai sekalian hadat menteriku. Hai sekalian gelarang aku menyaksikan perkataanku dan perjanjianku ini kepada Allah Ta'ala Tuhan yang maha esa dan kepada Rasul Allah penghulu kita Nabi Muhammad saw dan kepada sekalian malaikat Allah Ta'ala, maka barang siapa yang merombak dan melalui perjanjian aku dengan kedua guruku itu sampai dengan tujuannya sebagai dalam BO ini, itulah orang yang dimurkai Allah dan Rasulnya ada 
segala malaikat niscaya orang ini tidaklah mendapatkan selamat dunia akhirat, Wallahu kairusy-syahidin. ${ }^{4}$

Nampaknya Kegiatan pendidikan waktu itu dapat dikatakan berarti baru setelah berdirinya kesultanan Bima dan dilantiknya Sultan Abdul Qahir sebagai Sultan pertama. Hal ini dapat diketahui bahwa sudah menjadi kelaziman bagi seorang Sultan untuk medidik putera-puteranya. Ini tiada lain untuk menyiapkan anak didiknya agar mampu melaksanakan tugas-tugasnya kelak setelah ia dewasa. Atas dasar pemikiran tersebut, para sultan dan keluarganya serta para pembesar istana lainya berusaha menyiapkan agar anak-anaknya sejak kecil sudah diperkenalkan dengan lingkugan dan tugas-tugas yang akan diembannya nanti, oleh karena itu, mereka memanggil guru, guru khusus untuk mengajar anak-anak mereka.

Sehubungan dengan kebiasan-kebiasan Sultan tersebut, dapat disebut sebagai contoh seperti Sultan Abdul Qahir Sirajuddin mengajak Datuk Raja Lela sebagai guru di istana yang sekaligus juga merangkap sebagai penasehat baginda. Demikian pula Syekh Umar Al-Bantany menjadi guru di istana pada masa Sultan Nurudin yang di nobatkan sebagai Sultan Bima pada bulan Zulhijah 1093 H/1682 M. Di lingkungan Istana, Syek Umar Al-Bantany di samping mendidik keluarga putra Sultan, juga menjadi mufti waktu itu. Atas pengaruh beliau pada zaman itu, jabatan keagamaan kesultanan Bima disempurnakan dengan mengadakan jabatan qadli, lebe, khatib dan lain-lain. Sebagai pendidikan di istana beliau berhasil membina putra mahkota yang setelah dewasa di kenal dengan Sultan Jamaluddin Aly Syah Sultan ke empat. Akibat didikan gurunya, Sultan Jamaluddin Aly Syah terkenal sebagai seorang patriot, politikus, yang cinta tanah air dan agamannya. ${ }^{5}$ Demikian juga pada masa Sultan Ibrahim banyak guru yang didatangkan ke Istana untuk mendidik putra-putranya. Putra-putranya banyak menerima pendidikan agama dari para ulama. Putra putrinya banyak memperoleh pendidikan agama dari para ulama terkenal di antaranya H. Hasan Batawy, Syek Abd. Wahab, imam masjidil Haram Mekkah.

Pendidikan anak-anak di istana berbeda dengan pendidikan-pendidikan pada umumnya. Di istana orang tua murid (para pembesar Istana) adalah yang membuat rencana pelajaran tersebut selaras dengan kebutuhan anaknya dan tujuan yang dikehendaki orang tua (Sultan) oleh karena itu guru yang mengajar di Istanah di sebut Muaddib.

Kata muaddib berasal dari kata "Adab" yang berarti budi pekerti atau meriwayatkan. Guru pendidikan di istana sisebut muaddib, krena berfungsi mendidik budi pekerti dan mewariskan kecerdasan dan pengetahuan-pengetahuan orang-orang terdahulu kepada anak-anak pejabat.

${ }^{4}$ M. Hilir Ismail, Peranan Kesultanan Bima dalam Perjalanan Sejarah Nusantara (Bima: 1988), hal. 44 .

${ }^{5}$ H. Fauzi Bafadal, Sejarah Pendidikan Serah NTB, (Jakarta: Projek Inventarisasi dan Dokumen Kebudayaan Daerah, 1984), hal.27 
Karena itu rencana pelajaran untuk didikan anak dilingkungan kesultanan Bima waktu itu selain belajar agama Islam (rukun, iman, rukun Islam, thaharah,adab), juga ditambah dan dikurangi menurut kemauan para pembesar yang bersangkutan, dan selaras dengan keinginan untuk meyiapkan putra-putrinya secara khsusus untuk tujuan-tujuan dan tanggung jawab yang dihadapinya dalam kehidupan ini. Melaksanakan aktivitas pendidikan Islam bagi putra-putra sultan Bima waktu itu, sebenarnya bertujuan mengikuti keteladanan apa yang pernah dilakukan khalifah/penguasa terhadap putra-putranya pada awal munculnya Islam di tanah Arab. Sebab bukti sejarah mecatat bahwa kebiasaan-kebiasaan itu merupakan suatu kelaziman bagi seorang khalifah/sultan. Kegiatan pendidikan Islam di istana sebagaimana yang diuraikan di atas membawa pengaruh yang luas dikalangan masyrakat, sehingga banyak dari mereka yang berdatangan untuk belajar agama Islam dan berguru kepada mubalig/guru di istana untuk beberapa lama. Murid-muridnya kemudian kembali ke daerah pedalaman menjadi guru pula di tempat asalnya masing-masing. Maka tersebarlah sampai di kampung-kampung guru-guru agama Islam yang mengajarkan agama dan mereka pula yang merintis berdirinya tempat ibadah, pendidikan untuk anak-anak baik dirumah, surau maupun masjid. Pendidikan agama untuk anak-anak tebina dengan baik.

Dengan dibentuknya majelis agama Islam sebagai badan eksekutif kesultanan maka kegiatan pendidikan Islam lebih aktif dan terkoordinir. Dengan bersfungsinya lembaga tersebut secara efektif, aktivitas pendidikan semakin semarak dan mulai terkoordinir dari tingkat pusat kesultanan sampai desa-desa. Sekalipun demikian belum ada satupun lembaga pendidikan Islam dalam bentuk formal.

Untuk tingkat pusat, terdapat pejabat yang bertanggung jawab terhadap pelaksanaan pendidikan Islam bagi Sultan dan keluarganya yaitu para qodli dan imam, sedangkan yang bertanggung jawab terhadap pelaksanaan pendidikan Islam bagi masyarakat secara keseluruhan yaitu Lebe Na'e untuk tingkat kejenelian/kecamatan, dan Cepe Lebe untuk tingkat desa serta Robbo untuk tingkat kampung.

Bahkan pada setiap malam Jum'at bagi setiap Lebe Na'e dan Cepe Lebe untuk setiap tingkat kejenelian dan desa diwajibkan datang ke istana kesultanan untuk diadakan evaluasi terhadap bacaan mereka tentang Al-Qur'an (tajwid) dan yang mengadakan evaluasi adalah sultan itu sendiri. Sebab sudah menjadi kelaziman untuk setiap sultan memahami agama, bahkan tidak jarang sultan hafal Al-Qur'an.

Kegiatan pendidikan Islam di istana membawa pengaruh luas di kalangan masyarakat, sehingga banyak dari mereka yang berdatang utntuk belajar agama Islam dan berguru kepada mubalig/guru di istana untuk beberapa lama. Muridmuridnya kemudian kembali kedaerah pedalaman dan menjadi guru pula ditempat asalnya masing-masing. Maka tersebarlah sampai kekampung-kampung guru-guru agama Islam yang mengajarkan agama dan mereka pula yang merintis berdirinya tempat ibadah, pendidikan untuk anak-anak baik dirumah, surau maupu masjid, pendidkan agama Islam untik anak-anak terbina dengan baik.

Kemudian setelah resmi menjadi kesultanan Bima dan Abdul Qahir di lantik sebagai sultan Bima yang pertama mulai nampak aktivitas pendidikan Islam, 
baik dipusat kesultanan surau, masjid maupun dalam lingkunagan keluarga masyarakat secara luas. Yang menjadi materi pelajaran adalah berkisar pada permasalahan rukun iman, rukun Islam, thahara, sopan santun.

Untuk lingkungan Istana, khusus bagi putra-putra Sultan, pendidikan disesuaikan dengan situasi dan kondisi waktu itu.

Sultan Abdul Qahir membangun lembaga-lembaga pendidikan, lembaga pendidikan ini merupakan faktor penunjang dalam perkembangan Islam di daerah Bima. Pada masa Sultan Abdul Qahir dan perdana mentri yang bernama Abdul Hamid, pada dasarnya lembaga yang bernama saranan Hukum didirikan untuk lembaga pemerintahan kerajaan Bima.

Pada masa Sultan Abdul Qahir dan perdana mentri Abdul Hamid banyak mendirikan lembaga-lembaga pendidikan antara lain:

1. Membangun masjid pertama yang diberinama Masjid Kamina, yang terletak di Desa Kalodu kecematan Langgudu kabupaten Bima yang berjarak sekitar 75 kilometer dari Kota Bima, masjid itu berbentuk segi empat besar yang bersimbol empat putra dan keluarga kerajaan yang memeluk Islam pertama kali yaitu: Abdul Qahir, Awaluddin, Jalaluddin dan yang terakhir Sirajuddin selain itu juga menjadi simbol empat mubalig yang menjadi guru bagi keluarga kerajaan yang berasal dari tanah Gowa, Tallo, Luwu dan Bone, bertiang delapan dan segi delapan yang bersimbolkan Nggusu waru atau segi delapan yang merupakan jumlah empat keluarga mubalig. M. Amin, mengatakan bahwan :

Masjid tersebut memiliki nilai sejarah yang tinggi. Dahulunya putra kerajaan Bima, Jena Teke la Kai Atau putra mahkota La kai mendirikan masjid tersebut pada $1631 \mathrm{M}$ setelah masuk Islam, dia menganti nama dengan Abdul Qahir. Abdul Qahir membangun masjid tersebut sebagai persembunyian dari pamannya Salisih yang berambisi merebut kekuasaan dengan dibantu Belanda.

Dengan bantuan Belanda, Salisih berhasil mengembalikan alih kekuasaan kerajaan tampa persetujuan lembaga hadat Dana Mbojo (pemerintah kerajaan) pada waktu itu.

2. Membentuk kelompok dakwah diberbagai daerah khususnya yang memiliki keterkaitan dengan kerajaan.

\section{Bidang Dakwah}

Pada abad $17 \mathrm{M}$ pengaruh Islam hampir merata diberbagai wilayah penting di Nusantara tidak hanya di Sumatra. Jawa dan Sulawesi tetapi juga sudah sampai di Bima Nusa Tenggara Barat. Yang pada mulanya hanya disebarkan oleh para pedagang dan mubalig yang telah menyebarkan agama Islam di pulau Sumatra terkenal dengan Waingapu.

Sedangkan penyebaran Agana Islam di Sulawesi Selatan dan Bima terkenal dengan tiga mubalig yakni Datuk ri Bandang dan Datuk ri Tiro dan Datuk Sulaiman, kemudian yang sampai dan menyebarkan agama Islam di kerajaan Bima adalah Datuk ri Bandang dan Datuk ri Tiro. Dalam penyebaran agama Islam ini mereka mengambil metode Dakwah yang cukup berhasil yang dilakukan oleh para 
mubalig adalah dengan cara pendekatan kepada masyarakat seperti, penyesuaian diri dengan situasi dan kondisi masyarakat, yang sudah berpegang teguh pada kepercayaan lama Animisme dan Dinamisme.

Para mubalig dan penyiar agama Islam itu dalam menghadapi hal yang demikian mereka tinggal diam. Dengan semangat dan usaha keras mereka berupaya untuk merubah adat istiadat kebiasaan itu, dengan memberi dakwah agar masyarakat yang baru mengenal agama Islam tidak merasa terhina dan tersinggung atas kepercayaan lama mereka.

Metode dakwah yang seperti tersebut diatas adalah dengn melihat situasi dan kondisi masyarakat memang sudah dicontohkan oleh Nabi Muhammad saw. Ketika pengikut beliau masih sedikit. Tetapi setelah mempunyai pengikut banyak yang dan memiliki kekuatan diperkirakan dapat mengalahkan lawan, maka beliau melakukan dakwah secara terang-terangan, bahkan komprontasi, tapi apabila beliau melihat bahwa lawannya tidak mungkin dapat dikalahkan maka beliau megambil startegi menghindar atau atau dengan kata lain berhijrah.

Staregi yang ditempuh oleh Nabi Muhammad saw. Telah menunjukan bahwa agama Islam disiarkan bukan dengan kekerasan atau paksaan melinkan dengan cara damai dan bijaksana. Seperti halnya dengan penyebaran agama Islam yang dijalankan di Bima dengan cara damai dan penuh bijaksana. Agama Islam itu tersiar bukan dengan pedang melainkan dengan Dakwah (seruan) Allah berfitrman:

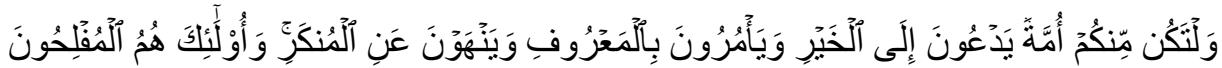

Terjemahan;

"Hendaklah diantara kamu segolongan umat yang menyru kepada kebijakan, menyeru berbuat baik dan mencengah dari perbuatan yang mungkar (perbuatan keji/maksiat) merekalah orang-orang beruntung. ${ }^{6}$

(Q.S.Al Imran:104)

Dalam peristiwa-periatiwa sejarah penyebaran agama Islam, maka seluruhnya telah memperlihatkan bahwa ajaran yang telah ditempuh untuk tersiar dan perkembangannya ialah dakwah (seruan) dan tidak pernah Islam memakai kekerasan $^{7}$

Kemudian pendekatan yang kedua yakni dakwah lewat masjid, mushallah dan langgar dan setelah Raja memeluk agama Islam ia memerintah untuk membangun sebuah masjid dengan bentuk yang sederhana dan masjid terebut terletak di Kalodu yang merupakan masjid pertama di kabupaten Bima.

Pembangunan masjid tersebut merupakan suatu langkah untuk pengembangan agama Islam sebab merupakan sebagai pusat peribadahan dan sebagai pusat agama Islam yang masih memakai sistem pendidikan yang bersifat Alfatih,2009)

${ }^{6}$ Alqur'an Departemen Agama RI, Al-qur'an dan Terjemahannya,(Jakarta: Pustaka

${ }^{7}$ A. Syalabi, Sejarah dan Kebudayaan Islam (Cet. i. Jilid I; Yogyakarta: PT. Djaya Murni, 1970), h. 107 
kedaerahan. Oleh sebab itu, pendidikan di masjid merupakan salah satu sarana untuk mempercepat penyebaran agama Islam keseluruh daerah pedalaman ilmu pengetahuan mereka tentang agama Islam.

Setelah mereka belajar, ada diantara mereka yang kembali kedarahnya untuk memberikan pelajaran agama kepada keluarganya yang belum menganut agama Islam. Dengan demikian akan menjadi lancarlah hubungan antara penduduk pedalaman dan pelabuhan semakin ramai dikunjungi oleh para pedagang kedaerah pedalaman sendiri maupun dari luar pulau Jawa, Sumatra, Sulawesi Selatan dan bahkan dari luar negeri.

Dengan adanya perdagangan-perdagangan dari Bugis-Makassar tidak sedikit artinya bagi Masyarakat Bima, bahwa merekalah yang banyak memegang peranan perdagangan di Bima. Kemudian mereka berkebumi ke daerah-daerah pedalaman untuk mencari dan mengumpulkan hasil hutan dengan cara berdagang seperti itu, mereka sangat membantu dalam usaha menyebarkan agama Islamdi kerajaan Bima terutama di daerah pedalaman.

Bidang dakwah dilakukan oleh para mubalig yang memang bertugas khusus untuk menyebarkan agama Islam. Di jawa meskipun pada mulanya Islam disebarkan melalui perdagangan tetapi penyebaran melalui dakwah.

Menurut sumber Bima, bahwa Sultan Abdul Qahir dikirim secara resmi untuk menyebarkan agama Islam ke daerah timur khusunya, Ende, Waingapu, Bajo dan Reo. Kedatangan mereka atas permintaan orang-orang yang sudah tertarik dengan Islam baik dari mubalig Gowa maupun dari Jawa, sasaran dakwah mereka adalah para penguasa daerah setempat dalam hal ini raja. Apabila penguasnnya sudah menganut agama tidak menutup kemungkinan rakyatnyapun akan mengikut. Dalam melakukan dakwah, mubalig dari Bima sudah berhubungan baik dengan masyarakat Nusa Tenggara Timur. Berkat ketabahan mubalig dari Bima karena bantuan dari orang-orang Gowa yang sudah menetap di Flores Barat, Alor dan Solor usaha penyebaran itu berhasil walaupun tidak dapat mengislamkan seluruh masyarakatnya, karena mendapat halangan dan rintangan.

Kemudian Para ulama dan guru agama sangatlah dihormati dan para pemuda yang rajin mempelajari agama serta yang kuat mempelajari ibadah, dikirim ketanah suci Mekkah untuk menunaikan ibadah haji dan memperdalam ilmu Agama. Kerajaan Bima yang didirikan atas restu Ncuhi (restu adat) berakhir ketika mengalir ajaran baru yang datang dari sumatra dan Sulawesi. Begitupun kerajaan laut majapahit runtuh oleh orang dalam. Jawa pecah dan meningkatkan dinamika diantara saudagar-saudagar tionghoa muslim. Gujarat dan Eropa maka gerakan Islam atau gerakan ekonomi yng berbendera Islam mendominasi kekuasaan baru di kawasan baru, yaitu dikawasan pesisir meluas dan termaksud merajai tanah Sulawesi, sehingga merebes kekerajaan Bima yang tidak jelas agama resminya.

Islam sudah memasuki pulau Sumbawa sejak awal abad ke-60 oleh penyiar dari kerajaan-kerajaan pesisir Jawa seperti Demak, namun semakin jelas ketika saudagar dan penyiar Islam datang dari Sulawesi, Goa, Tallo melalui pintu perairan Bima dan Sape. Tahun 1600-an. Pada masa itu Bima tengah dirajai oleh La Kai salah satu raja yang sudah mengidentifikasi diri sebagai Putra Bima bukan lagi 
nama Jawa seperti Indra Zamrud, Batara Bima , Batara Indra Bima disebut. La kai adalah raja Bima abad $17 \mathrm{M}$, dan menjadi raja pertama yang menerima Islam sebagai agama resmi yang boleh disebarkan di Bima, dia sendiri menjadi muslim dengan mengubah nama menjadi Abdul Qahir.

Setelah raja masuk Islam maka Islam menjadi agama resmi istana dan penyebaran menjadi mudah dengan menggunakan perangkat kekuasaan. Maka sejak itu budaya penamaan orang Bima berubah menjadi nama-nama berbau Arab dan Timur Tengah, misalnya La mbila menjadi Jalaluddin, Bumi jara mbojo menjadi Awaluddin, Abubakar, Siti hawa, Aminah, Nurul, Ismail, Syarifuddin, Abdullah. Masuknya Islam di Bima bersamaan dengan konflik internal Istana, dimana salah satu pembawa besar istana Salisih Mantau Asi Peka yang melakukan teror dan pembunuhan pada beberapa penguasa wilayah, dan gerakan ini diam-diam disokong oleh serikat dagang VOC yang sudah masuk di Bima dalam misi dagang. Dijadikannya Islam sebagai gama resmi istana membawa keuntungan sendiri bagi kerajaan Bima. Karena pada zaman imperium Sulawesi Sedang berjaya diseluruh kawasan Timur Nusantara dan mengibarkan bendera Islam dalam segala misinya termasuk menghalang keutamaan VOC dan portugis yang mulai memperkuat tentaranya dengan berisan meriam.

Rupanya kondisi ini di mainkan oleh Belanda VOC dengan menyongkong pemberontakan Salisih duduki, sehingga dalam waktu yang reltive singkat kerajaan Bima berhasil di duduki oleh pemberontak. Raja Bima sendiri yang masih muda pengalam bersama Lambila penasehatnya berhasil menyelamatkan diri dan dia mendukung penuh untuk merebut kembali kekuasaan kerajaan Bima meskipun pemberontakan itu di dukung oleh VOC.

Maka sultan Alauddin Awalul Islam mulai mengirim pasukan untuk menyerang Bima dalam kekuasaan pemberontakan dan berhasil memukul mundur mereka, sehingga barisan La Salisih Mantau Asi Peka melarikan diri ke Dompu. Setelah berhasil merebut kembali mereka kembali kekuasaan maka Sultan Abdul Qahir dan rombongannya kembali ke Bima. Dan setelah tiga bulan kemnali ke Bima Abdul Qahir kukuhkan kembali sebagai Sultan pertma Bima, yang menandai berakhirnya sistem kerajaan. Jadi dapat di ketahui bahwa yang mendorong Islam masuk di Bima itu ialah karena Dakwah Islamiyah sebeb mereka datang ke Sape itu merupakan utusan resmi yang sengaja di kirim oleh penguasa Makassar untuk penguasa di Bima, melalui pelabuhan Sape. Karena pelabuhan Sape Waktu itu merupakan satu-satunya pelabuhan di Bima yang menghubungkan Jalur Utara. Sehingga jalan perdagangannya menjadi rantai. Bahkan dua tahun sebelum tiba para pedagang yang membawa Agama Islam ke Bima melalui pelabuhan Sape, Jelasnya pada tahun 1025/1615 M, Sultan Alauddin sebagai penguasa kerajaan Gowa wktu itu pernah mengirim Surat untuk penguasa kerajaan Bima karena mereka sama-sama dalam kerajaan berserikat.

Dan adapun isi pokok dari surat tersebut memberitahu bahwa Kerajaan Gowa Tallo sudah masuk Islam. Adapun bunyi lengkap surat ialah :

Kemudian dari pada itu bersetuju degan bunyi perjanjian dengan kerajaan bersahabat, kakanda yang bertahta atas kerajaan Gowa dan Tallo menjadi 
kerajaan Islam, yaitu kerajaan yang berpegang atas keyakinan, "tiada tuhan yang disembah melainkan Allah, dan Muhammad itu Rasul-Nya". Serta di dalam memerintah kerajaan ini mereka wajib mencengah keburukan dan menjalankan kebenaran. Demikian adinda maklum adanya. Tertulis di kota Makassar di dalam benteng Somba Opu pada tanggal 11 hari Bulan Muharram sanat 1025 dan dibumbuhi tanda tangan oleh I manggarangi daeng manrabia ia bergelar Sulan Aalauddin.

Jadi masuknya Islam ke Bima ialah Dakwah Islamiyah atau seruan amar ma'ruf nahi mungkar. Hal ini tertera dalam isi surat penguasaan kerajaan Gowa tersebut. Yang merasa berkewajiban untuk menjalankan kebenaran dan mencengah kemungkaran. Sedangkan faktor perdagangan merupakan alternatif sebagai faktor pelengkap.

Mengenai Dakwah dengan surat/tulisan dalam penyebaran Islam bukan hal yang baru. Rasullulahpun berdakwah dengan mengirim surat-surat kepada pembesar-pembesar dunia waktu itu. M. Yunan Nasution menyebut tentang Dakwah Rasullulah melalui surat:

Bahwa di zaman jalur-jalur komunikasi belum seperti sekarang ini Rasullulah menyampaikan surat-surat yang merupakan Dakwah dalam bentuk tulisan kepada beberapa pembesar dunia pada waktu itu dan umumnya mendapat sambutan positif dan mencapai sukses. ${ }^{8}$

Dari keterangan di atas dapat diketahui bahwa saranan penyampaian Da'wah yang diterapkan oleh Sultan Aaluddin sebagai penguasa kerajaan Gowa yang ditunjukan penguasa kerajaan Bima waktu itu sesuai dengan yang pernah diterapkan oleh Rasullulah sendiri. Barangkali Sultan Aluddin mempunyai penilaian bahwa pengaruh Da'wah dengan tulisan ini lebih sesuai dengan situasi dan kondisi waktu itu sehingga beliau mengajak penguasa Bima lewat surat.

\section{Kesimpulan}

Proses pegangkatan seorang Sultan di Bima dilakukan melalui proses pemilihan, Sultan dipilih oleh raja atau majelis Hadat bersama Majelis Hukum, Sultan Abdul Qahir dilantik menjadi Sultan pada tanggal 15 Rabi'ul Awal 1050 H/1630 M, di lantik di atas Tanah Makambuju (Gunduhan Tanah), dengan demikian Resmilah berdirinya kerajaan Bima yang berjiwa Islam.

Sultan Abdul Qahir membangun lembaga-lembaga pendidikan, lembaga pendidikan ini merupakan faktor penunjang dalam perkembangan Islam di daerah Bima. Pada masa Sultan Abdul Qahir dan perdana mentri yang bernama Abdul Hamid, pada dasarnya lembaga yang bernama saranan Hukum didirikan untuk lembaga pemerintahan kerajaan Bima.

${ }^{8}$ M. Yunan Nasution, Dakwah dengan Tulisan Panjimas, no 249 (15 juni 1978), hal.12. 


\section{DAFTAR PUSTAKA}

Alqur'an Departemen Agama RI, Al-qur'an dan Terjemahannya, Jakarta: Pustaka Alfatih,2009.

Abdillah, Aam Pengantar Ilmu Sejarah, Cet., I; Bandung: Pustaka Setia, 2012.

Abdullah Achmad BA, Kerajaan bima dan keberadaannya. Cet. I; Raba-Bima Perpustakaan Nasional 1992.

Haif, Abu RIHLAH jurnal Sejarah dan Kebudayaan: Sejarah Perkembangan peradaban Islam di Mesir, Makassar: Jurusan Sejarah dan Kebudayaan Islam Fakultas Adab dan Humaniora UIN Alauddin, 2015.

Ahmad, Amin, Ringkasan Sejarah Bima., Bima: Kantor Kebudayaan Kabupaten Bima, 1971.

Andanang Taruna, "Sultan Abd. Hair" Majalah Harmoni, No. 121, Th. Ke VII, 1 Desember 1996.

A. Syalabi, Sejarah dan Kebudayaan Islam, Cet. i. Jilid I; Yogyakarta: PT. Djaya Murni, 1970.

Hj. Sitti Mariam R. Salahuddin ddk, Aksara Bima: Peradaban Lokal yang Sempat Hilang, Mataram : Alam Tara Institute, bekerjasama dengan : sampa raja kota bima, 2003.

H. Munawir Sjadzali, Islam dan Tata Negara, Cet. II; Jakarta: Universitas Indonesia, 1990.

M. Hillir Ismail, Peranan Kesultanan Bima dalam Perjalannan Sejarah Nusantara Bima, thn. 1998.

Miriam Budiarjo, Dasar-dasar Ilmu Politik, Jakarta : PT Granmedia Pustaka Utama, 2008.

Rahmat, ddk. Buku Daras Praktek penelusuran Sumber Sejarah dan Budaya, Cet. I; Jakarta : Guna Darma Ilmu.

Nasution, M. Yunan, Dakwah dengan Tulisan Panjimas, no 249 (15 juni 1978). 